\title{
Mangifera indica and Phaseolus vulgaris in the Bioindication of Air Pollution in Bahia, Brazil
}

\author{
J. S. Lima, ${ }^{*, 1}$ E. B. Fernandes, ${ }^{*}$ and W. N. Fawcett $\dagger$ \\ *Universidade Federal da Bahia, Instituto de Biologia 40170, 290 Salvador-Ba-Brasil, and $\dagger$ Kings College, London
}

Received August 3, 1999

In this article are reported the results of a study on the concentration of ascorbic acid (AA) in Mangifera indica as passive monitor and in Phaseolus vulgaris as active monitor with the intention to study the effects of industrial emissions from the Petrochemical Complex of Camaçari (PCC), Bahia, Brazil, on the vegetation. Leaves from $M$. indica were collected in two sites in the region under direct influence of industrial emissions and in one presumed nonpolluted reference (background) site. Pots with $P$. vulgaris were exposed in the same sites. The AA increase in the leaves of $M$. indica from PCC sites indicates a stress situation. The small AA increase in the $P$. vulgaris exposed in the more polluted site indicates that the active monitor is a sensitive one. The decrease of its leaf area indicates the inability of this specie to activate physiological protection mechanisms like an increase in AA production. (c) 2000 Academic Press

Key Words: ascorbic acid; air pollution; Mangifera indica; Phaseolus vulgaris; Brazil.

\section{INTRODUCTION}

Brazil today has air pollution, and the genesis of these problems is largely the industrial politics that have been adopted for the development of the country. In 1978, the largest petrochemical complex in South America began operation in Bahia, northeast of Brazil $\left(12^{\circ} 33^{\prime}-13^{\circ} 10^{\prime} \mathrm{S}\right.$; $\left.38^{\circ} 00^{\prime}-39^{\circ} 00^{\prime} \mathrm{W}\right)$. A high priority has been given to industrial development. A network of air monitoring (CETREL) set up by the industries to monitor emissions and atmospheric conditions was installed at the end of 1994. However, emissions data are scarce, inefficient, and often not available to the public. Since the end of 1995, a biomonitoring network has been installed in the region of the Petrochemical Complex of Camaçari (PCC) (Klumpp et al., 1998).

According to Campos (1995) and Tavares and Campos (1997) the PCC is the greatest source of $\mathrm{SO}_{2}$ and $\mathrm{NO}_{x}$ in the region. Oil combustion for energy production alone causes

${ }^{1}$ To whom correspondence should be addressed. E-mail: joslima@ ufba.br. the emission of ca. 60,000 and 80,000 tons $\mathrm{SO}_{2}$ per year. Ozone is also an important pollutant, exceeding sporadically the hourly rate of $100 \mathrm{ppb}$, according to the CETREL report of 1995. The national standard rate for ozone is $80 \mathrm{ppb} \approx \mu \mathrm{m} / \mathrm{m}^{3}$ (Cetesb, 1995).

Little information exists about the effects of the emissions originating from the PCC on the ecosystem. Lima et al. (1997a), using Sphagnum sp and Coriandrum sativum to monitor heavy metal concentrations, found a significant increase of arsenic and copper concentrations in the sites near a copper processing industry. Lima et al. (1997b), using Cymbopongon citratus to monitor emissions effects, made a positive correlation between copper content in the leaves and a decline in the biomass.

The analysis of indigenous plants, such as Mangifera indica, can provide useful information in monitoring the quality of air and the effects on vegetation under the direct influence of the petrochemical complex. Because of its abundance, $M$. indica seems to be tolerant to air pollution stress. Plant bioindication is a useful tool for pollution monitoring, as the plants themselves are strongly integrated into the environment in which they live and the parameters such as physiological responses can be measured under natural conditions. The use of passive bioindication has the advantages of giving an indication of the present state of the organism and vegetation, the effects of air pollution on plant vitality, and detection of mechanisms of resistance against pollutants on plant vitality, and detection of mechanisms of resistance against pollutants (Domingos et al., 1998). As early as 1911 , Soraver suggested the use of $P$. vulgaris as an indicator for air pollution monitoring (Dässler and Börtitz, 1998). According to Zaffari and Oliva (1989), P. vulgaris is one of the most useful species for the assessment of $\mathrm{SO}_{2}$ effects. Low $\mathrm{SO}_{2}$ concentrations provoke rapid visible symptoms like necrosis, reduction of foliar area, and foliar loss. Arndt et al. (1987) concluded when P. vulgaris is exposed to open air, it responds to different kinds of pollutants. According to the author, P. vulgaris presents visible symptoms in concentrations between 0.02 and $0.05 \mathrm{ppm}$ ozone. 
Rennenberg and Polle (1994) stated that it was "generally assumed that damage by Sulphur Dioxide is the result of free radical formation in the chloroplast." This is where the highest levels of ascorbic acid are found. They went on to say that "where superoxide formation is essential to obtain Sulphur dioxide damage, this may be prevented by processes reducing these levels including ascorbic acid, superoxide dimutase and reduced glutathione." Treshow and Anderson (1989) stated that free radicals can be formed but can be impaired by protective natural scavengers and that ascorbic acid may be the most important of these. Winston (1990) proposes the possibility that, as ascorbic acid is hydrophylic, it can "protect lipid membranes by scavenging free radicals in the aqueous phase of the cell, thereby preventing their attack on the lipid membrane." Chameides (1988) suggested that in the case of ozone, ascorbic acid alone could provide a fast enough reaction to "mop up" all the ozone that entered the cell. Heath (1996) commented that some of these argument rested on "shaky ground" but that overall it was a "coherent argument." All these arguments indicate that ascorbic acid is indeed important in the protection of plants against the effects of oxidizing pollutants and an increase in pollutant stress should lead to an increase in the ascorbic acid content of the leaf.

\section{STUDY SITES}

The Petrochemical Complex of Camaçari has a superficial area of 1300 ha, about 526 a, comprising 52 plants form private Brazilian and international business groups to produce first-, second-, and third-generation petrochemicals, plastics, resins, fibers, and fertilizers. The PCC is fringed by two of the region's main river basins (Joanes and Jacuipe Rivers) near the north coast of the state of Bahia, northeastern Brazil, between the municipalities of Camaçari and Dias D’Ávila.

Considered to be part of the Brazilian low lands, the region where the $\mathrm{PCC}$ is located presents a flat topography with small bumps, with an altitude varying between 60 and $200 \mathrm{~m}$. The relief is classified as plain, almost uniform, composed of neritic sediments (Paleozoic and Mesozoic), presenting low coastal elevations and dunes rounded in the form of a half-moon and elevations more stressed, with a flat top, in the form of a table, called "tabuleiros." The form of the coastal profile of the region, or its shoreline, presents itself quite linearly, a typical characteristic of the Brazilian Northeastern litoral zone. According to studies developed by Nieuwolt (1977) and Pielke (1984) this form of shoreline does not influence either the intensification or the weakening of either sea or land breezes.

The main wind circulation in the PCC region, during daytime, is due to the sea breeze, which occurs in response to the horizontal gradient of pressure, resulting from the differential heat between the continent and the ocean. During the night, the circulation inverts, originating the land breeze. The winds that blow on the PCC region often have speeds between 0.5 and $1.0 \mathrm{~m} / \mathrm{s}$ (Araujo and Frondizi, 1991) and act to renew the air of the coastal area. This characteristic, on one hand, avoids atmosphere stagnation, but on the other, acts as a transporter of pollutants. It should be noted that, in general, the PCC region is ventilated with a low percentage of calms $(2.9 \%$, according to Araujo and Frondizi, 1991).

The vegetation in the vicinity of PPC fits together like a mosaic in which there is a mixture of native forest species such as dense ombrophilous forest in various stages of conservation, scrub ("cerrado"), "restinga," mangrove, and areas altered by man. The native vegetation is also mixed with subspontaneous specie. Pine and eucalyptus are also prominent after having been introduced to provide protection to the forest and act as pollutant screens, soil stabilizers, and noise breakers. Different levels of damage can be observed in the vegetation. Information about the extent of the ecosystem damage is not available.

For the development of this work, three sites were chosen: one of them in an area free of direct influence of the emissions of the PCC, called UFBA (reference site), and the other two under the direct influence of emissions, called Lamarão and Sítio. The reference site at UFBA (Federal University of Bahia), which is located $55 \mathrm{~km}$ from PCC, in the middle of Salvador city, has a good wind system and little circulation of vehicles, so the pollution stress should be lower. It is however in a developing city where levels of pollutant stress are still probably higher than the "natural" levels. The Lamarão site is located $12 \mathrm{~km}$ northwest from the PCC and the Sitio site is located $8 \mathrm{~km}$ northwest from the PCC. The climate of the study areas is warm and moist $\left(A_{f}\right)$. According to Köppen, the annual temperature is about $25.3^{\circ} \mathrm{C}$ and the precipitation is between 1700 and $2000 \mathrm{~mm} /$ year. Table 1 presents the concentration of some pollutants emitted in the PCC region.

TABLE 1

Concentration of Emission Components in the Petrochemical Complex of Camaçari

\begin{tabular}{lcc}
\hline $\begin{array}{l}\text { Charge of pollutants } \\
\text { emitted (t/year) }\end{array}$ & 1994 & 1995 \\
\hline Particle material & $2.951,3$ & $2.257,48$ \\
$\mathrm{SO}_{2}$ & $33.815,9$ & $26.924,9$ \\
$\mathrm{CO}$ & $18.218,1$ & $17.646,74$ \\
$\mathrm{NO}_{x}$ & $14.716,2$ & $14.026,71$ \\
Organics & $13.683,3$ & $14.339,14$ \\
\hline
\end{tabular}

Source. CETREL report (1995). 


\section{MATERIAL AND METHODS}

\section{Active Monitoring}

Before being transported to the field, plants of $P$. vulgaris (carioquinha) were cultivated in pots in a greenhouse at the Biology Institute of the Federal University of Bahia, using a standard substrate (Plantmax-Eucatex) and adequate fertilizer and irrigation (Arndt et al., 1987). Six days after germination, six plants were exposed at each site for 27 days, after which they were taken to the laboratory and conserved in liquid nitrogen, where the ascorbic acid content was determined. Ripe or complete grown leaves were subjected to analysis following the methodology described in Keller and Schwager (1977). Statistical analysis was made with the SAS program; significant differences between samples were determined by Tukey tests $(P \leq 0.05)$.

\section{Passive Monitoring}

At each site, four $M$. indica adult individuals were randomly selected. Ten leaves of each tree were taken. All the leaves collected were taken from shaded parts of the tree. This helps to avoid any artificially high levels of ascorbic acid caused by the presence of higher light levels. To ensure each leaf was approximately the same age and had similar characteristics, the fifth leaf from each stem was collected in each case. The samples were subjected to the same ascorbic acid analysis procedure used for the active monitoring.

\section{RESULTS}

Figure 1 indicates that passive monitoring ( $M$. indica) presented clearly higher levels of ascorbic acid in the sites located under direct influence of the Petrochemical Complex of Camaçari emissions, while active monitoring $(P$. vulgaris) reveals more elevated concentration only in the

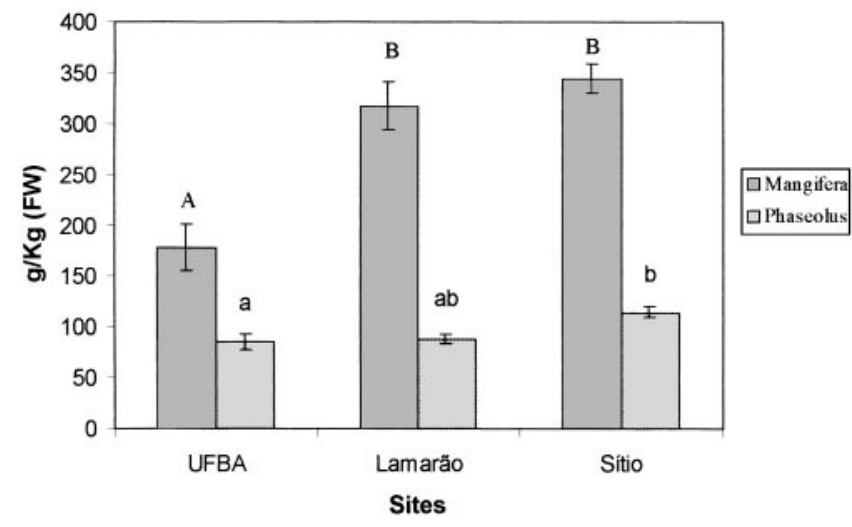

FIG. 1. Levels of ascorbic acid in leaves of Phaseolus vulgaris and Mangifera indica under the influence of air pollution. Columns with the same letters are not statistically different. Tukey test $(P \leq 0.05)$.

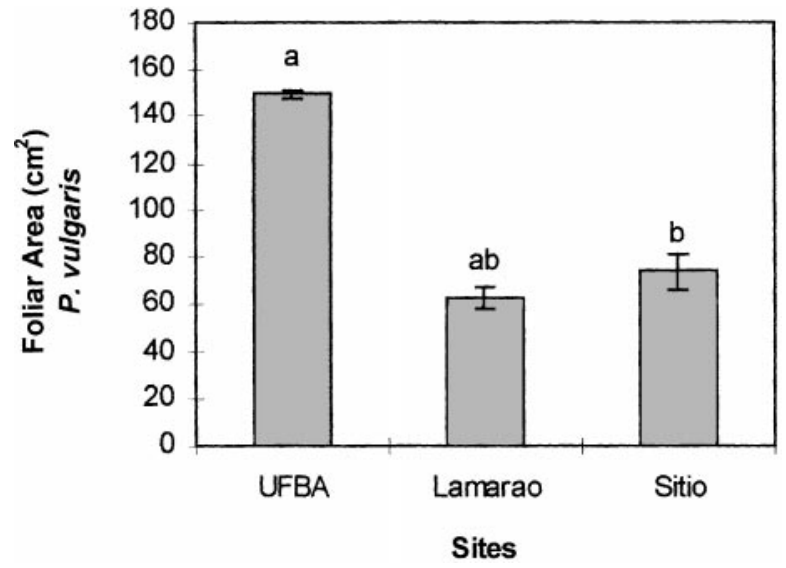

FIG. 2. Foliar area of Phaseolus vulgaris. Columns with the same letter are not statistically different. Tukey test $(P \leq 0.05)$.

Sítio site, which is nearest to the PCC. The concentrations in the plants exposed in sites Lamarão and UFBA were similar.

The suitability of Phaseolus can be seen in Fig. 2, which exhibits the influence of the emissions on the development of the leaf area. No significant differences could be seen in the leaf area of $M$. indica from the investigated sites.

\section{DISCUSSION}

Considering the AA concentrations, the passive monitor $M$. indica appears to be a resistant species, while the $P$. vulgaris a sensitive one. A direct relationship between endogenous levels of ascorbic acid and plant susceptibility to pollutants has been established (Iqbal and Yunus, 1996). Varshney and Varshney (1984) reported higher ascorbic acid concentrations in leaves of $\mathrm{SO}_{2}$-resistant species compared to sensitive ones and a slower decline of ascorbic acid in the former. The increase in the level of ascorbic acid in the leaf reflects the need for reductive processes to counteract the effects of oxidative pollution. Ascorbic acid is a natural antioxidant in plants and plays a role in reactions involved in the critical line of defense against oxidative damage, associated with the production of oxyradicals. Ascorbic acid has been found to play an important role in pollution tolerance (Keller and Schwager, 1977). Lewin (1976) points out that its reducing power is dependent on its concentration; therefore the increase in levels of ascorbic acid in the leaf from site UFBA to the sites at the PCC reflects effects of higher oxidative pollution.

The ability of ascorbic acid to act directly as a scavenger of superoxide and singlet oxygen has been postulated. It has also been suggest that through its ability to scavenge alkoxyl radicals, ascorbate inhibits propagation reactions. Ascorbic acid was found to inhibit the oxidative breakdown of polyunsaturated fatty acids, which would suggest that 
ascorbic acid affords some protection to the cell membrane. Ascorbic acid is one mechanism used to detoxify toxic molecules also including enzyme systems, vitamin E, peptides, carotenoids, polyamines, and organic buffering systems. It has been suggested that the interaction of vitamin $\mathrm{E}$ with ascorbate affords a synergistic antioxidant protective effect as opposed to either of the compounds alone (Doba et al., 1985; Barclay et al., 1985).

\section{CONCLUSION AND SOME PERSPECTIVE}

The Petrochemical Complex of Camaçari began operations in 1978 and until now there is little information about the effect of air pollution on the ecosystem. The results of this work indicate that $M$. indica is a resistant plant against air pollution. It can probably be used as a passive monitor, making possible, in addition to other information, a mapping of the region, where the higher polluted areas can be identified. Efforts should be urgently applied to produce more reliable data or publish information about the concentrations of air pollutants and to start an effective and interdiciplinary biomonitoring program.

\section{ACKNOWLEDGMENT}

The authors thank Bernadefe Marcello for the revision.

\section{REFERENCES}

Araújo, M. A. A., and Frondizi, C. (1991). Levantamento da Micrometeorologia e Influência Topográfica, Relatório Cetrel R2/R3.

Arndt, U., Nobel, W., and Scweizer, B. (1987). Bioindikatoren-Moglichkeiten, Grenzen und neue Erkentnisse. Ulmer-Verlag, Stuttgart.

Barclay, C. R. C., Locke, S. T., and Macneil, J. M. (1985). Autoxidation in micelles. Synergism of Vitamin E and water soluble Trolux. Can. J. Chem. 63, 366-374.

Campos, V. P. (1995). Especiação inorgânica de enxofre, nitrogênio e cloro na precipitação seca e úmida no Recôncavo Baiano. UFBA, Salvador, Tese de Doutorado.

Companhia de Tecnologia de Saneamento Ambiental (CETESB) (1995). Relatório de Qualidade do Ar no Estado de São Paulo, 1994. CETESB, São Paulo.

Empresa de Proteção Ambiental (CETREL) (1995). Rede do Monitoramento do Ar: Relatório Anual Camaçari, BA.

Chamedies, W. L. (1988). Chemistry of ozone deposition to plant leaves: The role of ascorbic acid. Environ. Sci. Technol. 23(5), 595-599.
Dassler, H. G., and Börtitz, S. (1988). Air Pollution and its Influence on Vegetation. Tradução: Dr. Eva Katzer, Jena, GDR DRW. Junk Publishers.

Doba, T, Burton, G. W., and Ingold, K. U. (1985). Antioxidant and co-antioxidant activity of Vitamin C. Biochim. Biophys. Acta. 835, 298-303.

Domingos, M., Klump, A., and Klump, G. (1998). Air pollution impact on the Atlantic forest in the Cubatão region of S. P. Brazil. Ciência e cultura J. Bazil. Assoc. advance. Sci. 50(4), July/August.

Heath, R. L. (1996). Oxidant induced alteration of carbohydrate production and allocation in plants. In Change Effects on Forest Ecosystems. University of California website.

Iqbal, M. and Yunus, M. (Eds.) (1996). Plant Response to Air Pollution, pp. 195-215. Wiley, New York.

Keller, Th., and Schwager, H. (1977). Air pollution and ascorbic acid. Eur. J. Forest Pathol. 7, 338-350.

Klumpp, A., Domingos, M., and Lima, J. S. (1998). Einsatz subtropischer und tropischer Pflanzenarten als Bioindikatoren für Luftverunreinigungen in der Umgebung brasilianischer Industriezentren. Postbeitrag zum 1. A. F. W. Scimper-Symposium, Ökologische Forschungen ausserhalb Europas, Tropenzentrum Hohenheim, Jahresbericht 1998 Seite 64.

Lewin, S. (1976). Vitamin C: its Molecular Biology and Medical Potential. Academic Press, San Diego.

Lima, J. S., Filho, D. M. C., Couto, E., Santana, D. L., and Souza, H. C. (1997a). de. Comparação entre o coentro e o Sphagnum sp. como bioacumuladores do arsênio no Pólo Petroquímico de Camaçari-BA. Rev. Brasil. Ecol. 1(1), 91-94.

Lima, J. S., Filho, D. M. C., Couto, E., Korn, M. G. A., Melo, M. H., and Gomes, R. C. T. (1997b). Capim-Santo (Cymbopongon citratus) como bioindicador de poluição atmosférica no Pólo Petroquímico de Camaçari-BA. Rev. Brasil. Ecol. 1(1), 95-98.

Nieuwolt, S. (1977). Tropical Climatology. Wiley, Chichester.

Pielke, R. A. (1984). Mesoscale Meteorological Modeling. Academic Press, New York.

Rennenberg and Polle (1994). Metabollic consequences of atmospheric sulphur influx into plants. Chapter 9 from: Plant responses to the gaseous environment-Molecular, metabollic and physiological aspects. Edited by Alscer \& Welburn. Chapman \& Hall.

Tavares, T. M., and Campos, V. P. (1997). Ambiente atmosférico. In Baia de Todos os Santos-diagnósitco sócio ambiental e subsídios para a gestão, pp. 79-109. Germen/UFBA-NIMA, Salvador.

Treshow, M., and Anderson, F. K. (1989). Plant Stress from Air Pollution, pp. 44-52. Wiley, New York.

Varshney, C. K., and Varshney, S. R. K. (1984). Effect of low levels of CO2 on glutamate dehydogenase in crop plants. Biochem. Physiol. 179, 433-437.

Winston, G. W. (1990). Physiochemical basis for free radical formation in cells; production and defenses. In Stress Response in Plants-Adaptation and Acclimatization Mechanisms, pp. 57-86. Wiley-Liss, New York.

Zaffari, G. R., and Oliva, M. A. (1989). Alterações fisiológica em Phaseolus vulgares L., cv. negrito-897 submetido a diferentes doses de dióxido de enxofre. Rev. Brasil. Fisiol. Veg. 1(1), 19-24. 